\title{
Pásztor Szabolcs
}

\section{A tér és a közgazdaság-tudomány kapcsolatának korlátai a határ menti területek kutatásában}

\begin{abstract}
A tanulmány az ismert közgazdasági elméletekböl kiindulva közelíti meg a továbbfolytatódó kereskedelmi liberalizációnak, integrációnak és a határok eltünésének lehetséges következményeit. A kérdések, hipotézisek megfogalmazása után a szerző azt mutatja be, hogy a különböző közgazdasági elméletek hogyan látják az integrációtés a határokeltünését a határmentiterületekfejlődésétilletően. A közgazdasági elméletek eredményein keresztül felvázolja azon téregységek fejlődési pályáját, melyek életében jelentős befolyásoló szerepet tölt be az államhatár, majd az elméletek legfontosabb eredményeit összegezve arra a következtetésre jut, hogy egyelöre a csökkenő kereskedelmi költségekhez kapcsolódó regionális átrendeződés domborodik ki az integráció területi hatásával kapcsolatosan. Felhívja a figyelmet arra is, hogy az elméletek nem adnak egyértelmü és tiszta válaszokat, ezért a határ menti területek fejlödésének kutatásában a kizárólagos közgazdasági megközelítés túlzottan leegyszerüsítő lehet, tehát leginkább empirikus kutatás vezethet az integráció hatásainak pontos feltérképezéséhez.
\end{abstract}

Journal of Economic Literature (JEL) kód: F15, O18, R12

Kulcsszavak: európai integráció, határ menti területek, közgazdasági elméletek

Tanulmányomban a tovább folytatódó kereskedelmi liberalizáció, az európai integráció és a globalizációs tendenciák kapcsán kívánom felvázolni a határ menti területek általános fejlődési pályáját. ${ }^{1}$ Munkámmal egy speciális kérdéskör tudományos igényü vizsgálatára vállalkozom, mivel a közgazdaság-tudomány önállósulása után hamar elveszítette területi dimenzióját, és a main-stream közgazdasági elmélet gyakorlatilag térnélküli pontgazdaságok müködési jellemzőit kutatja. Ez azonban természetesen nem jelenti azt, hogy a kezdetektől ne jelentek volna meg olyan közgazdászok és közgazdasági elméletek, melyek a térbeli termelésitényező-áramlásoknak, a nemzetközi tényezőallokációnak ne tulajdonítottak volna nagy jelentőséget (Benko 1999).

Dolgozatomban azért helyezek nagy hangsúlyt a megannyi globalizációs tendencia között az eltűnő határok kérdésére, mert a nemzeti határok állandósult változása, mozgása a határok fizikai helyét, illetve gazdasági jelentőségét illetően az egész világon, így az Európai Unióban (EU) is jellegadóvá vált (Ohmae 1995). Ebben a megváltozott helyzetben a határok és a határ menti területek növekvő mértékben esnek a keveredési, összeolvadási, elmosódási zónák fogalma alá, ahol mind az anyagi és a szimbolikus dimenziók, mind

Pásztor Szabolcs PhD-hallgató a Debreceni Egyetem Közgazdaság-és Gazdaságtudományi Kar Világgazdaság és Nemzetközi Kapcsolatok Tanszékén. E-mail: szabolcs.pasztor@econ.unideb.hu.

1 Annak ellenére teszem ezt, hogy ismerem azokat a megközelítéseket, amelyek szerint a határ nyitottsága nem mindig hoz kézzelfogható eredményt. Leginkább olyan esetek említhetőek, amikor a két elválasztott ország között nincs lehetőség jelentős kereskedelmi forgalom kialakítására, például a gyenge gazdasági integráltság miatt (Krakover 1997). 
a hatalmi kapcsolatok találkoznak egymással (Bhabha 1994; Thrift 1996). A határok és a határmentiség kérdéskörének tanulmányozása különösen az EU-ban igazán fontos, hiszen a 2004-es és a 2007-es bővítés után az államhatárok együttes hossza immáron 26 ezer 160 kilométer, s 62 van belőlük. Arra is rá kell mutatnunk továbbá, hogy jelenleg az EUval közvetlenül 16 ország érintkezik, ahol összességében majdnem 400 millióan laknak (Kallioras et al 2009).

Ha korábbi tendenciákat veszünk alapul, akkor azt várhatjuk, hogy az EU továbbra is határ menti integráció marad, ahol a regionális együttmüködésen belül a mesterséges határok felszámolása különbözö tendenciákat indít el (Hanson 1996, 1998b). Az 1950-es és az 1980-as évek között az államhatárok stabil képződmények voltak Európában, az 1990es években azonban radikális gazdasági, társadalmi és politikai változások következtek be, melyek jelentősen érintették a határokat is (Anderson - O’Dowd 1999). Látni kell azonban azt is, hogy az O'Dowd és Wilson által vizionált "határok nélküli Európa” (Europe without borders) koncepciója még nem öltött testet, mert egyelöre számos esetben - ilyen például Közép-Kelet-Európa - nem beszélhetünk határmentes gazdasági térségről. Következésképpen, a határok még mindig fontos szerepet töltenek be a területi folyamatokban, és nagyban meghatározzák a határ menti térségek fejlődési lehetőségeit. Az átlagos határrégió túlnyomórészt távol esik a központi magterülettől, a határ továbbra is jelentős interakció-szükítő szerepet tölt be, ezáltal ezek a területek a nemzeti átlag alatti fejlettségi szintet mutatnak (Petrakos - Topaloglou 2008). Ezért fontos tehát az európai integráció határ menti területek fejlödésére gyakorolt hatásának, valamint makro- és mikroszintű vonatkozásaiknak a vizsgálata (Topaloglou 2008).

Tanulmányomban először makroszinten vizsgálódom, és több kérdésre keresem a választ. Milyen módon és milyen mértékben vesznek, vehetnek részt a határ menti területek az integrációs folyamatban? A határok jelentősen átalakulnak-e, és az akadályok hidakká válhatnak-e, vagy esetleg alagutakká formálódnak, s így a közvetlenül a határ mellett fekvő területek semmit sem profitálnak az intenzívebb interakciókból? Az általában kevésbé fejlett határrégiók előnyt tudnak-e kovácsolni a határon átnyúló nemzetközi kereskedelemből és befektetési kapcsolatokból, vagy csak folyosóként szolgálnak ezekben az áramlásokban? Arra is kíváncsiak lehetünk, mennyire határozza meg a földrajzi elhelyezkedés a határon átnyúló interakciók szintjét. Számos határ menti terület ugyanis távol esik az EU központi piacaitól, és nem rendelkezik a földrajzi közelség stratégiai előnyével. Fontos ezért tudnunk, hogy az előbbi tényező mennyire határozza meg a határon átnyúló interakciók kialakulását és formálódását. További kérdésként merül fel, vajon igaz-e, hogy az EU magterületei közelében lévő régiók más jellegủ és szintű integrációt mutatnak, mint a távoliak? Arra is kíváncsiak lehetünk, hogy a múlt öröksége mennyire határozza meg a kialakuló integrációs szintet.

Ha mikroszintre tereljük a vizsgálatainkat, akkor leginkább a kereskedelmi kapcsolatok hajtóeröire lehetünk kíváncsiak. Egyelöre nem lehetünk bizonyosak afelől, vajon a földrajzi elhelyezkedés vagy a piacméret a fontosabb. Nagyobb hangsúlyt kapnak esetleg a közeli területek, mint a távoliak? Egyáltalán, milyen jellegü és erősségü területi dinamizmusok, energiák szabadulnak fel?² 
A kérdések megválaszolása a közgazdasági elméletekhez tereli a kutatót. A határ menti területek fejlődése és az integrációban betöltött szerepük a telephely, a kereskedelmi és az új gazdaságföldrajzi elméletekben jelenik meg. Talán élhetünk azzal a hipotézissel, hogy az empirikus kutatásokon alapuló elméleti megközelítés egyértelmủ válaszokat ad a felvetett kérdésekre, és a határ menti térségek fejlődési mozgástere az európai integrációban egyértelmüen felvázolható.

A tanulmány bevezető részében a kérdéseimet, hipotéziseimet fogalmazom meg, míg a második rész azt mutatja be, hogy a különböző közgazdasági elméletek miként látják az integrációt és a határok eltűnését a határ menti területek fejlődését illetően. Azért próbálok több nézöpontot vegyíteni, mert célom az, hogy egzakt képet alkossak a lehetséges fejlődési pályáról. A különböző elméletek bevonásával pedig Jules Henry Poincaré (1909) tudományos nóvumokkal szemben támasztott értékítéletéhez illeszkedem, mely szerint „Egy új eredmény akkor igazán értékes, ha egyenként már régóta ismert, de egymástól távol állónak tünő elemek közt létesit kapcsolatot, és ezzel hirtelen rendet teremt ott, ahol addig a rendezetlenség állapota uralkodott." A harmadik részben pedig az elméletek legfontosabb eredményeinek összegzésére és a következtetések levonására vállalkozom.

\section{Határrégiók a közgazdasági elméletek tükrében}

\section{Telephelyelméletek}

A telephelyelméletek fókuszában döntően lokalizációs kérdések állnak. A már régóta kutatott kérdéskör azonban korán interdiszciplináris jelleget öltött, melyben sajátos megközelítés született a határok és a határ menti területek kapcsán is (Christaller 1933; Giersch 1949/1950; Lösch 1944/1945).

A gazdasági integráció területi hatását elsőként Lösch (1944/1945) említi meg szilárd, következetes, ugyanakkor szokatlan modelljében (Bröcker 1990). E szerint a fogyasztók és a termelési tényezők immobilak és egyenletes eloszlást mutatnak a térben. A méretgazdaságosságot, a tökéletlen versenyt és a saját profitérdekeket figyelembe vevő vállalatok ezért ott telepszenek le, ahol a területileg szétszórt kereslet a legjobban kiszolgálható. A megközelítés természetesen számol a szállítási költségekkel is, amelyek a fogyasztók és a termelők távolságával arányosak. Ebből pedig az következik, hogy az adott pontról kiszolgált piacterület erősen determinált.

Mindezen megállapításokon Lösch hamar túllépett és kutatásainak központi problémája a piacterületek regionális rendszerelméletének fejlödése volt (Niebuhr - Stiller 2002b). Lösch elmélete szerint a központok piackörzetei elméletileg és zavartalan fejlődés esetén kör, illetve hatszög alakúak. A központból kiindulva tehát a földfelszín minden irányába terjednek, aminek az az oka, hogy a vállalatok hatszögletü piacterületeket fednek le, és céljuk a tér minden egyes pontjának elérése.

Egy erősen elválasztó határ esetében a városhálózat határhoz közeli egységei azonban rosszabb helyzetbe kerülnek, mint a nemzeti központhoz közelebbiek, mert az államhatár megbontja a Christaller-féle hatszöges rendben szerveződő hierarchiaszinteket és a határnyitás aszimmetrikusan hoz helyzetbe egyes központokat. Ebből következően pedig nem alakulhat ki teljes piac- és vonzáskörzet, vagyis a nemzeti határok megjelenésével a gazdasági terület nagyban torzul (Rechnitzer 1999; Niebuhr - Stiller 2002) (1. ábra). 


\section{A határok piackorlátozásban betöltött szerepe}

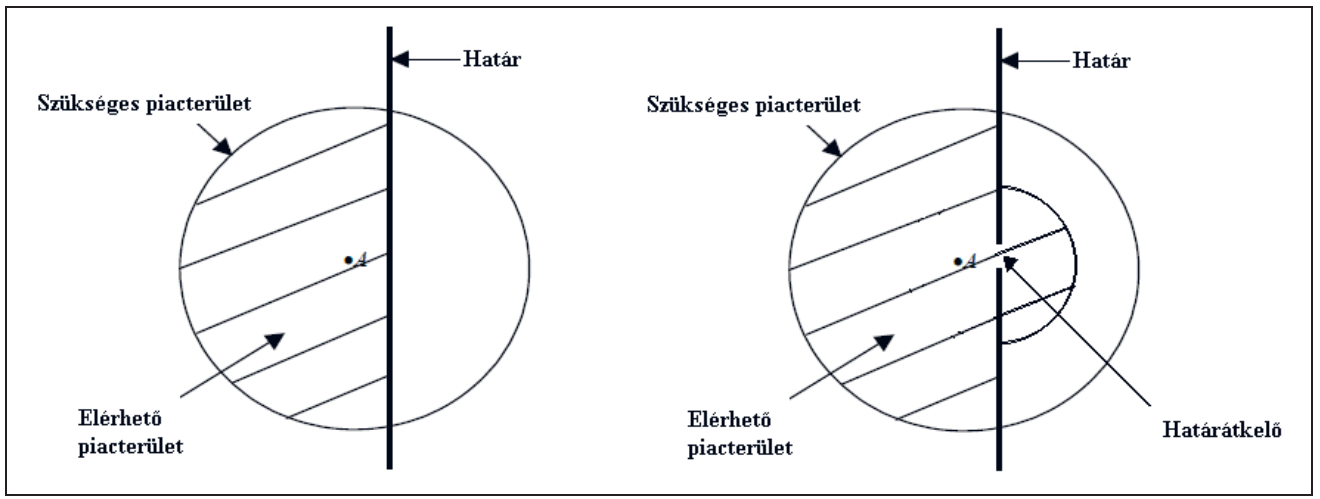

Forrás: Niebuhr - Stiller (2002b) alapján saját szerkesztés.

Az ábrából egyértelmüen látható, hogy a határok részleges vagy teljes átjárhatatlansága torzító elemként jelenik meg a piaci hálózatokban. Mindezt Nijkamp és szerzőtársai (1990) is megerösítik, amikor úgy fogalmaznak, hogy a határok jelentősen korlátozzák a személyek, az anyagi javak, az információ és a tudás szabad áramlását. A határkutatás egyik legkiválóbb képviselője, Anssi Paasi pedig ezt tovább árnyalva kifejti, hogy a határok helyi és nemzetközi szinten intézményekként (szürőkként) szolgálhatnak a belépés és a kilépés saját szabályainak meghatározásával, minden időben előírva a javak, a tőke, a szolgáltatások és az emberek szállításának mértékét (Paasi 1996). Egy határátkelő természetesen növeli az elérhető piacterület nagyságát, ám ez a terület a határ másik oldalán jóval szerényebb, mint az innenső részén (1. ábra). Ennek okaiként elsősorban a határátlépéshez kapcsolódó költségeket említhetjük (Topaloglou 2008).

Boggs (1940) minden más kutatónál karcosabban fogalmaz, s egyenesen azt hangsúlyozza, hogy az államhatárok a gazdasági integráció korlátai. Ennek tükrében pedig nem lepődhetünk meg azon, hogy az államhatárok egyértelműen a határon átnyúló interakciók gátjaiként jelennek meg a szakirodalomban. A kutatók széles körben rámutatnak: a határok növelik a nemzetközi kereskedelem, illetve az ipari termelés költségeit, s ezáltal jelentősen torzítják a piacot (Suarez-Villa 1992; Kamann 1993; Ratti 1993; Clark 1994). Engel és Rogers (1996) pedig még azt is megerősítik tanulmányukban, hogy a hasonló termékek árai jóval nagyobb szórást mutatnak a határ egyik, illetve másik oldalán lévő városban, mint azonos országban fekvő városok között.

A beszükülő gazdasági „játéktér” pedig érdemben befolyásolja a gazdasági teret (Hanson 1996, 1998b). Erre Haggett (2006) is rámutat, amikor arra a következtetésre jut, hogy a vámok és egyéb járulékos költségek többletkiadása jelentősen hozzájárul a piaci hatósugár beszúküléséhez. A piaci hálózatok torzulásával, illetve a potenciális piaci területek felszabdalódásával az anyagi veszteségek megjelenése pedig már tudományosan kellően alátámasztott tény (Lösch 1944/1945; Ratti 1993; van Houtum 2000; Baranyi 2007). A határok tehát megosztják a piaci területet, s ezáltal negatívan befolyásolják a vállalat 
piacpotenciálját. ${ }^{3} \mathrm{Az}$ alacsonyabb értékesítési volumen pedig arra is ösztönözheti a céget, hogy visszavonuljon az adott piacról. Ennek következménye pedig az lesz, hogy a határ közelsége miatt a vállalatok nem a határ menti területen telepszenek le.

Azt is látnunk kell továbbá, hogy minél távolabb lesznek a vállalatok a határtól és minél közelebb az adott ország földrajzi központjához, annál nagyobb lesz a szükséges piacterületük. A határrégiókban ennek megfelelően szerényebb volumenű lesz a gazdasági tevékenység, és csak olyan cégek fognak megjelenni, amelyek egyébként is kis piaci területet igényelnek. Lösch (1944/1945) ezért a határ menti területeket sivatagokhoz, elhagyatott területekhez hasonlítja. Ezekben a téregységekben sok terméket csak nagyobb távolságból vagy egyáltalán nem lehet beszerezni. A nagy távolság pedig a gazdasági tevékenységek „népszerütlen” területeivé teszi a határ menti területeket (Dimitrov et al 2002).

Számos más kutató (például: Giersch 1949/1950; Guo 1996; Heigl 1978; Nijkamp et al 1990; Erdösi 1988; Ruttkay 1995; Czimre 2006) is hasonló következtetésre jut. Olvasatukban a határ menti régiók hátrányos helyzetü területek, s ezt leginkább annak tulajdonítják, hogy a határok korlátozzák a javak fizikai áramlását. Van Houtum (2000) szerint a határrégiókat általánosságban marginális területekként tarthatjuk nyilván. Hátrányos helyzetük periférikus fekvésükből és a megosztott piacterületükből adódik, melynek további következménye a méretgazdaságosság szerényebb mértékü kihasználása.

Hoover (1963) tanulmányában jó összefoglalót ad a határok jelentőségéröl a tradicionális telephelyelméletek kapcsán. Megállapítja, hogy a vámok és más nemzetközi kereskedelmi korlátozások növelik a szállítási költségeket, megzavarják a piacterületet, az ellátási hálózatokat és növelik a határok közelében letelepedett termelők költségeit. Következésképpen, ő maga is arra jut, hogy a termelők nagy valószínüséggel elkerülik azokat a területeket, ahol valamilyen kereskedelmi korlátozó tényező miatt torzult piaci vagy kínálati terület jön létre. Ebből következően a vállalatok azon részeket fogják preferálni, ahol a központi fekvés jó hozzáférést biztosít a piachoz. Ezen „határhatás” következtében a cégek pedig egy határokkal körülzárt terület középső területe felé fognak orientálódni. Ennek egyértelmü hozadéka az lesz, hogy egy vállalat keresleti és kínálati kapcsolatrendszere sürübb szövetet alkot egy adott ország földrajzi középpontjában, mint a perifériáin (Niebuhr - Stiller 2002b).

Abban az esetben pedig, ha megfordítjuk az előző gondolatmenetet, rá kell mutatnunk a következőkre. A határok megnyílásával igen jelentős gazdasági átrendeződés figyelhető meg a határ menti területeken (többek között: Hansen 1986; Martinez 1986; Le Gales Lequesne 1998; Scott 1998; Slowe 1991; Williams et al 2001; Wilson - Donnan 1998). A határ menti területek jelentősen javíthatnak vonzóképességükön akkor, ha leépülnek a nemzetközi kereskedelem akadályai és megteremtődik a külföldi piacokhoz való „olcsóbb” hozzáférés. A határrégióban müködő vállalatok számára a határok kereskedelem elötti megnyitása növeli az elérhető piacterületet. Ennek pedig a sajátos következménye a vállalatok nemzeti határok közelébe való települése lesz. Az integrált piacterületen olyan új termékek jelenhetnek meg, melyeknél a korábbi kisebb nemzeti piac egyszerüen túl kicsit volt a nem jövedelmező kínálatnyújtás és méretgazdaságossági okok miatt. Mindez persze

\footnotetext{
${ }^{3}$ A piacterület torzulását azonban nem csupán a határ mint gát okozza. Akár nyitott határok esetében is a piacterület beszüküléséhez vezet az a tény, hogy a szomszédos ország gazdasági-társadalmi, vagy akár müszaki rendszerei kisebbnagyobb mértékben eltérőek, így egy határ menti város nem tudja vonzáskörzetét olyan szabadsággal kiterjeszteni a szomszédos határ menti területekre, mint saját nemzeti területeire. A két ország között tehát számos olyan eltérés lehet, amely megnehezíti, költségesebbé teheti a város-vidék kapcsolattartást a határon keresztül (Hardi 2008).
} 
csak akkor valósulhat meg, ha a vállalat a közös piac központi részén helyezkedik el, és az új piac elegendő potenciált biztosít. Abban az esetben, ha ez létrejön, a határ menti területek a hazai és a külföldi piacok találkozásánál jelentősen növelhetik termelésvonzó képességüket az integrációs folyamat során.

A leginkább a lösch-i megállapításokra alapuló kutatások mellett mások explicit módon foglalkoznak a gazdasági integráció területi hatásának olyan kérdéseivel, mint a kereskedelmi akadályok eltűnése és a tényező mobilitása európai országok között. Giersch a központi fekvésű határ menti területek kedvező fejlődési pályáját vázolja fel az Európai Közösségben (Giersch 1949/50). A továbbra is perifériaként, félperifériaként fennmaradó határ közeli téregységek azonban a szerény mértékben kiszélesedő piacokból csak kisebb mértékben, vagy egyáltalán nem profitálhatnak (Topaloglou - Petrakos 2008).

A telephelyelméletek megállapításait összefoglalandó kimondhatjuk, hogy a határ menti területek gyengén fejlettek egy zárt gazdaságon belül. A gazdasági integrációban számos esetben megjelenik e területek integrációjának pozitív hatása, ám ez kizárólag akkor lehetséges, ha ezen téregységek relatíve közel esnek a külföldi piacokhoz, és a nyitás után jelentősen növeli tudják piacpotenciáljukat, értékesítési lehetőségeiket. Mindebből pedig az következik, hogy leginkább a centrális fekvésü határ menti területeken indulhatnak el pozitív területi dinamizmusok. A periférián, a félperiférián elhelyezkedő határok eltünésével csak jóval szerényebb amplitúdójú pozitív hatások bontakozhatnak ki.

\section{Kereskedelemelméletek}

Az integráció területi hatása a telephelyelméletek mellett megközelíthető a nemzetközi tényezőáramlás vagy a kereskedelem szemszögéből is. A szakirodalomban a kereskedelmi elméleteknél kapnak helyet azok a változások, amelyek a kereskedelmi liberalizáció által a gazdasági tevékenység területi jellegében mutatkoznak meg (Brülhart 1998). A különböző kereskedelemelméletek és a határ menti területek fejlődési pályájának kapcsolatát egészen a klasszikusokig visszanyúlva kívánom bemutatni, s ezzel az a célom, hogy átfogó képet adjak a két terület lehetséges kapcsolódási pontjairól.

Adam Smith vizsgálataiban az abszolút elönyöknek a nemzetközi (értelemszerüen határokat átívelö) kereskedelemre és a tényezoáramlásokra gyakorolt hatására helyezte a hangsúlyt. David Ricardo érdeklődésének homlokterében ugyanez állt, ő azonban leginkább a komparatív előnyök tanulmányozása során ért el kiemelkedő eredményeket. A XX. század első felében, a marginalista forradalom után, Heckscher és Ohlin szintén ezen gondolatmenet mentén indult el. Modelljeik speciális jellemzője, hogy a „valós” euklidészi értelemben értelmezett tér - a korábbiakhoz hasonlóan - nem kap szerepet a tényezőáramlások vizsgálatakor. Továbbra is a tényezőellátottság, a régiók (országok) közti áramlások szabadságának mértéke és a tényező mobilitás lesz hangsúlyos.

Később, a neoklasszikus kereskedelem elmélet azt vallja, hogy a gazdasági integráció magasabb szintü specializációhoz vezet azon termékek keresletének növekedése következtében, amelyeket az adott régió belső komparatív előnyökön alapulva alacsonyabb költségen tud elöállítani. Így számos szerző szerint a határon átnyúló gazdasági kapcsolatok egy költséghatékonyabb területi munkamegosztáshoz vezethetnek (Nijkamp 1993; von Malchus 1994; Church - Reid 1995; van Houtum 2000). A neoklasszikus megközelítés rámutat továbbá arra is, hogy a liberalizáció eredményeként kibontakozó munkaerő határon átnyúló mobilitása mögött a munkanélküliség és a bérek szintjében való különbség 
húzódik meg, mely nivelláló módon hat. A post-neoklasszikus elméletek a migrációt komplex és összetett jelenségként vizsgálják, ahol a társadalmi (Sjaastad 1962; Todaro 1969; Fischer - Straubhaar 1996) és a szektorális (Harris - Todaro 1970) jellemzőknek is nagy jelentőségük van. Más elemzések a távolsághoz és a másik fél esetében az információ hiányához kapcsolódó költségeket emelik ki (Schwartz 1973; Tassinopoulos 1999; Jannsen 2000). A neoklasszikus kereskedelmi elmélet egyébként az eltérő termelési struktúrával rendelkező gazdaságok között zajló úgynevezett inter-indusztriális kereskedelemre dolgoz ki elméleti megközelítést.

Meg kell említeni a továbbiakban a közgazdasági elméletek egy szeletét, az 1950es évekig (Vinerig) visszanyúló integrációs elméletet, amely eredetileg a neoklasszikus kereskedelmi modellen alapul (Tovias 1991). Az ebben a témakörben készült tanulmányok a kereskedelem liberalizálása és a közös külső vámok felállítása nyomán bekövetkező termelési és fogyasztási változásokat elemzik, és sajnálatos tény, hogy nem kap kiemelt jelentőséget a területi dimenzió (Trón 2009).

A legújabb modellek a méretgazdaságosság és a monopolisztikus verseny jelenségeit is érintik, s ezekben a modellekben a nemzeti határok vámot vagy vámmentes "akadályt" jelentenek. Ezt erösíti meg van Houtum (2000), aki úgy fogalmaz, hogy a határok általánosságban csökkentik a nemzetközi kereskedelem volumenét. ${ }^{4}$

A hagyományos és az újabb kereskedelmi modellek egyértelmüen megállapítják, hogy a kereskedelmet gátló akadályok leépülése révén hajtott integráció növeli a nemzetközi kereskedelmet (Niebuhr - Stiller 2002b). Ez a jelenség természetesen nem hagyja érintetlenül a nemzetközi termékspecializációt sem, amelynek fö mozgatórugója az országon belül bekövetkező termelési tényező reallokáció. A termelési tényezőkkel kapcsolatosan az lehet a kiinduló feltételezésünk, hogy azok teljes egészében mobilak országokon belül és szektorok között, míg teljes egészében immobilak nemzetközi szinten. Ezáltal az országoknak fix tényezőadottságai vannak, és a kereskedelemre mint a tényező mobilitás helyettesítőjére tekinthetünk. Ha a termelési tényezők immobilak, akkor nincsenek szállítási költségek sem nemzeti, sem nemzetközi szinten. Ezért minden egyes országot úgy kell kezelnünk, mint egy hatékony egyedülálló földrajzi lokációt. Mivel a nemzetközi kereskedelemelméleti modellek a nemzeteket a tér dimenzió nélküli pontjaiként kezelik, ezért be kell látnunk, hogy nem alkalmasak az integráció speciális hatásainak elemzésére.

Mint ahogyan Kovács (2010) megállapítja, a hangsúly magán a tényezőáramláson van, nem pedig az azokat befolyásoló térbeli sajátosságokon, meghatározottságokon. A földrajzi távolság helyett ugyanis inkább a „költségtávolság” jelenik meg a modellekben, a szállítási költség nemzetközi kereskedelmet befolyásoló negatív hatása révén. Ennek a költségtényezőnek a megbecslése pedig egészen népszerü kutatási területet kínál (Mackay 1958; Bröcker 1984; Nuesser 1985; Rietveld - Janssen 1990).

Az a feltételezés, hogy a térbeli távolság nem meghatározója a kereskedelmi kapcsolatok intenzitásának, ellentmondásban áll a gravitációs modellek empirikus becsléseivel, amelyek a távolságot a nemzetközi kereskedelem volumenének nagyon fontos meghatározó elemének tartják. El kell fogadnunk azt a tényt, hogy a kereskedelmi modelleknek is

${ }^{4}$ Ezt tovább árnyalva Bröcker (1984) megállapítja-amit később Nuesser (1985) és Bruinsma (1994) is megerösít-, hogy egy átlagos nyugat-európai országhatár olyan hatással bír, mintha egy adott ponttól 375 kilométeres távolságban vizsgálódnánk, másképpen a határ menti térségek nemzetközi kereskedelmi forgalma akár hatszor akkora is lehetne, ha nem lenne ott az országhatár. 
figyelembe kell venniük az egységre jutó távolsági költségeket, melyeknek természetesen számos következménye lesz (például területi struktúrák megjelenése). Foglalkozniuk kell továbbá a tényező mobilitással, ugyanis ha ezt nem teszik meg, akkor kihagyják az integráció egyik fontos tényezőjét.

Elöször Ohlin (1967) próbálkozott a kereskedelmi modellek „területmentes” struktúrájának leküzdésével, amikor kísérletet tett a telephely és a nemzetközi kereskedelmi elméletek bevonására. A legfontosabb megállapítása az volt, hogy a nemzetközi kereskedelem minden fontosabb eredménye alkalmazható az interregionális kereskedelmi kapcsolatokra is.

Később Rauch (1991) próbálkozik kisebb téregységek, városi települések gazdaságainak és a kereskedelem elméletek elemeinek vegyítésével. Ezáltal egy olyan modellt készít, amelyben a területi jelleg is megjelenik. Megközelítésében országon belüli és országok közötti szállítási költségek határozzák meg a kereskedelem volumenét. Modelljében kikötővárosok jelennek meg mint a gazdasági tevékenységek legfőbb vonzásközpontjai, ugyanis alacsonyabb a hozzáférési költségük a külföldi piacokhoz. Egyensúlyi állapot esetén a népesség nagysága, a városokban realizált bér és a bérleti díjak egyöntetűen visszaesnek, ha a kikötők felől az ország belseje felé haladunk. Be kell látnunk tehát, hogy egy régió földrajzi elhelyezkedése a nemzetközi kereskedelem regionális alkalmazkodása szempontjából fontos.

Ennek oka pedig az, hogy a hely meghatározó elem a külföldi piacokhoz való hozzáférés költségében. A külföldi piacokhoz való közelség előnyös azon vállalatok számára, amelyek erősen exportorientáltak, és az elhelyezkedés maga a gazdasági fejlődést is katalizálhatja.

Természetesen a kereskedelem nem csak kikötőkön keresztül zajlik, hanem szárazföldön is. Ebből a nézőpontból szemlélve a határ menti területeknek földrajzi elönye lehet az exportorientált vállalatok telepitésében, mivel azok földrajzilag közelebb esnek a külföldi piacokhoz.

Mindent összevetve, ha a regionális integrációs hatások elméleti megközelítésére vállalkozunk a kereskedelmi modelleken belül, akkor számos akadályba ütközhetünk. Nem kell azonban elhanyagolnunk ezt a kérdéskört, ugyanis a modellek nagy relevanciával bírnak az integrációs kérdéseknél. Arról van ugyanis szó, hogy a kereskedelem liberalizációja és annak megannyi hatása megjelenik a nemzeti termékstruktúra esetében. Sajnálatos tény viszont: egyelöre nem kapunk képet arról, hogy a makroszintü termelési struktúra hogyan befolyásolja az országon belüli régiókat. Mindebből pedig arra a következtetésre juthatunk, hogy igazából nem tudható, a kereskedelmi liberalizáció mennyire vagy miként befolyásolja a határ menti területeket. Egy hipotézisünk azonban biztosan igazolható: a termelési tényezők szektorok közötti reallokációja területileg különböző hatásokat eredményez országokon belül. Ez jelenik meg Rauch már említett modelljében, amely explicit módon foglalkozik a kereskedelem lokációs hatásaival. Ezen modell feltételezéseiből kiindulva az állítható, hogy azok a határ menti régiók, amelyek alacsonyabb költségekkel érnek el külső piacokat, természetes termelési zónák lesznek (Hanson 1996).

\section{Az új gazdaságföldrajz (New Economic Geography) elméletei}

A New Economic Geography (NEG) elmélet megszületése az úgynevezett centrumperiféria modellt megalkotó Krugman (1991) nevéhez füződik. Tudnunk kell azonban, hogy a későbbiekben Krugman és más szerzők sok vonatkozásban módosították az alapul szolgáló elméleti keretet és a NEG modellek széles palettáját fejlesztették ki. A megközelítések 
a gazdasági tevékenységek térbeli eloszlásával foglalkoznak és a regionális különbségeket teljes egészében endogén lokalizációs döntésekkel magyarázzák (Niebuhr - Stiller 2002a).

A modellek közös tulajdonsága, hogy kombinálják a hagyományos regionális tudomány és az új kereskedelem elmélet elemeit. Krugman saját maga a NEG modellt olyan lokalizációs modellnek tartja, amelyet a kereskedelmi elmélettel foglalkozók is értelmezni tudnak. Mint a hagyományos lokalizációs modellek, a NEG is pusztán statikus elméletként indult, de később - ellentétben a Lösch sorába illeszthető lokalizációs modellekkel - általános egyensúlyi modellként jelent meg.

Az NEG modellek jellemzői az explicit területi struktúra, az interregionális kereskedelmi költségek, a méretgazdaságosság a termelésben, s ezzel összhangban a monopolisztikus verseny (Niebuhr - Stiller 2002a). Az elmélet szerint a területi egyensúly a vállalatok és a dolgozók (fogyasztók) lokalizációs döntéseinek eredményeként jön létre. A dolgozók és a vállalatok kiegyenlített eloszlása a térben a centripetális erők (melyek elősegítik a gazdasági tevékenységek földrajzi koncentrációját) és a centrifugális erők (melyek segítik a gazdasági tevékenységek földrajzi diszperzióját) relatív erősségétől függ. Ha a centripetális erők az erösebbek, akkor a dolgozók és a vállalatok egyenlötlenül oszlanak el a térben. Ebben az esetben olyan agglomerációk jönnek létre, ahol nagy a gazdasági tevékenységek sürüsége, és lesznek olyan régiók is, ahol csak néhány vállalat, illetve szerény gazdasági tevékenység található. Ezt mutatja be Heigl (1978), amikor azt feszegeti, hogy a még korábban összetartozó téregységeket megosztó határ egyik, illetve másik oldalán is új gazdasági központok alakulnak ki (2. ábra).

2. ábra

\section{A határok centripetális hatása}

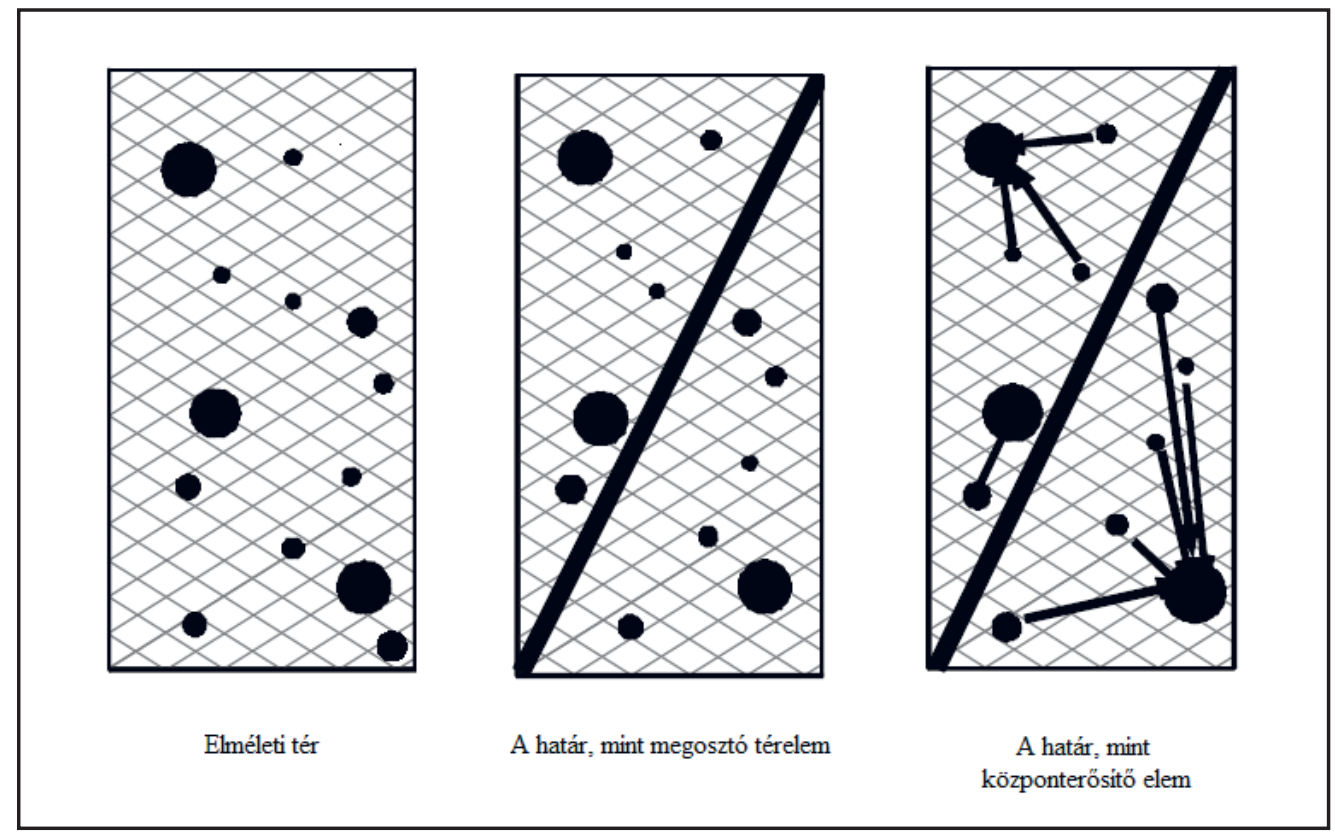

Forrás: Heigl (1978) 
A centrifugális hatások létrejöhetnek az agglomerációkban jelentkező immobil termelési tényezők relatív szükössége, vagy az úgynevezett non-tradable javak (például lakások) alapján, ugyanakkor az agglomeráció gyenge külső gazdasági integráltsága is meghatározó lehet. A vállalatokat és a fogyasztókat a régióba vonzó centripetális erők forrásaként a vállalati profitra, illetve a fogyasztók hasznára jelentős pozitív hatást gyakorló relatíve nagy lakáspiac említhető. Mindez pedig számos, a termeléshez és a fogyasztáshoz kapcsolódó hátramutató és előre irányuló tovagyürüző hatáshoz (backward and forward linkages) vezet. A dolgozók természetüknél fogva például a relatíve nagy piacokat preferálják. Ennek pedig az a magyarázata, hogy sok helyben előállított fogyasztási cikket érhetnek el, s ezáltal saját jövedelmüket növelhetik (forward linkage). Egy nagy piac közelében a vállalatoknak jó hozzáférésük van a kész vagy félkész termékek vásárlóihoz, ami pozitívan befolyásolja a profitot (backward linkage). A vállalatok továbbá területileg szétszóródnak, ugyanis jó hozzáférésük lesz a félkész inputok beszállítóihoz. Mindezzel szállítási és termelési költségeket tudnak mérsékelni (forward linkage) (Venables 1996; Puga 1999).

A backward és a forward hatások önmagukat erősítő agglomerációs folyamatokat indíthatnak el, mert az a nagyobb piac, ahol már egyébként is létezik a vállalatok és a dolgozók koncentrációja. Következésképpen, nagy egyenlötlenségek alakulhatnak ki a munkabérekben és a gazdasági tevékenységek sürüségében a gazdasági központ és a kevésbé fejlett hátország között. Ceteris paribus a reálbérek magasabbak a nagyobb piacokhoz közelebb esö területeken, mint a központtól távolabb lévö régiókban.

$\mathrm{Az}$, hogy a vállalatok területileg tényleg koncentrálódnak-e, továbbra is kérdéses lehet, mivel a gazdaságföldrajzi modellek általában többszörös egyensúlyt feltételeznek. A területi egyensúly konfigurációja a modellbe foglalt változóktól és a kiválasztott paraméterektől függ. Az interregionális kereskedelmi költségek szintje és a vállalatok, illetve a dolgozók feltételezett mobilitása erősen befolyásolja a centripetális és a centrifugális erők kapcsolatát. Az integráció hatással van ugyanis a nemzetközi szállítási költségekre, s könnyíti a határokon átnyúló tényezőáramlást, ezáltal megváltoztathatja a területi egyensúlyt is. Az integráció területi hatásával kapcsolatban pedig két új gazdaságföldrajzi modell hozható kapcsolatba:

1. A nemzetközi kereskedelmi költségek csökkenése és a határokon átnyúló munkaerőmozgások hatással vannak nemzetközi szinten a centripetális és a centrifugális erők egyensúlyára. Ezáltal az integráció megváltoztathatja a népesség, a termelési tényezők és a vállalatok eloszlását országok között (Ludema - Wooton 1999).

2. A nemzetközi kereskedelmi költségek hatással vannak a centripetális és a centrifugális erők egyensúlyára nemzeti szinten is, mivel a külföldi piacok jelentősége növekszik a vásárlók és a beszállítók számára. Ezáltal az integráció megváltoztathatja a népesség, a termelési tényezők és a vállalatok eloszlását országokon belül (Elizondo - Krugman 1996; Fujita et al 1999).

Ha a két nézőpont eredményeit vesszük figyelembe, akkor láthatjuk, hogy az integrációnak jelentős hatása van a gazdasági tevékenységek allokációjának alakitásában. Az első megközelítés szerint a tényezők liberalizációja és a kereskedelmi költségek csökkenése nagyobb munkaerő-piaci migrációt eredményez országok között. Az intenzívebb munkaerő-áramlás megváltoztatja a nemzeti erőforrás ellátottságát és ezáltal az ipari tevékenységek nemzetközi lokalizációját. A második feltevés az integráció országon belüli lokalizációs hatásaira fókuszál. Az említett tanulmányok Krugman úttörő NEG modelljének kiterjesztésére vállalkoznak és rámutatnak arra a tényre, hogy az árupiacok megnyitása hatással van az országon belüli gazdasági diszperzióra. Állításuk szerint, amíg 
a gazdasági tevékenységek lokalizációja egy zárt gazdaságon belül erősen befelé orientált, addig egy nyitott gazdaságban külső orientáció felé vált. A hazai piac kisebb jelentőségü lesz, és a hazai vonzásközpont relatív (valamint abszolút) vonzóképessége csökken. Mindez a gazdasági erőforrások reallokációját okozhatja országon belül, ráadásul úgy, hogy teljesen új központok jönnek létre.

A központi kérdés pedig továbbra is az, hogy a belső gazdasági térkép átrendeződésével a határ menti területek képesek-e a gazdasági tevékenységek kiterjedtebb színvonalú vonzására. Ezt a kérdést az utóbb említett két tanulmány nem veti fel. A szerzők hasonló külső kereskedelmi költségeket tételeznek fel egy országon belül minden viszonylatban, vagyis egyetlen régiónak sincs költségelőnye a másikkal szemben. Ám a külső kereskedelem regionális átrendeződésének legújabb szakirodalma szerint a határ menti területek pozitív hatások haszonélvezői az integrációban (Hanson 1996).

Az NEG-en alapuló piacméret megközelitések azt vetítik elöre, hogy a központi fekvésü határrégiók jelentös földrajzi elönyt élvezhetnek egy gazdasági unión belül. Ezen régiók relatív földrajzi elhelyezkedését markánsan megváltoztatja az integráció, ugyanis a nemzeti szintü periférikus helyzetből központi fekvésűekké válhatnak a közös piacon. A központi fekvésű határrégiók piaci hozzáférése, piacpotenciálja és piacmérete erőteljesen javul. ${ }^{5}$

A határrégiók hazai piaca növekszik, ha a határ két oldalán fekvő piaci területek egy piaccá olvadnak össze. Mindez akkor történik meg, ha határokon átnyúló backward és forward tovagyürüző hatások alakulnak ki. Ennek bekövetkezése az integráció magasabb fokán, a nemzeti határok jelentéktelensége mellett nagyon valószínű. A határon átnyúló kereskedelem növekszik az integrációban részt vevő országok között, ugyanis a vállalatok az outputjuk nagyobb részét adják el exportként, illetve a fogyasztók fogyasztásuk nagyobb részét fedezik importból. Ezen tényezők értelemszerüen számos vállalatot és fogyasztót vonzanak olyan régiókba, amelyeknek jó hozzáférése van a külföldi piacokhoz. Ilyenek pedig elsősorban a központi fekvésü határ menti területek lehetnek. A határrégiók vonzási potenciája még nagyobb lesz, ha a hazai és a külföldi vállalatok, iparágak vertikálisan kapcsolódnak egymáshoz, és erős a területi koncentrációra való hajlam (Venables 1996; Niebuhr - Stiller 2002b). Ebben az esetben a határokon átnyúló kapcsolatokkal rendelkező iparágak jelentős ösztönző erőt kapnak a területi agglomerációra, melynek elsődleges terepei a határrégiók lesznek. A kínálati és keresleti megfontolások együttesen azt vetítik elöre - a NEG megállapításaira támaszkodva -, hogy az EU mindenkori központi területeinek határrégiói lesznek a backward és forward tovagyürüzö hatásokat kihasználni tudó, kedvezö helyzetben lévö területek. Ebből pedig az következik, hogy az integráció új gazdasági központok kialakulását is magával hozhatja a határrégiókban (Fujita - Mori 1996).

A NEG modellek legfontosabb megállapítása tehát az, hogy a központi fekvésü határ menti területek az integráció által előidézett piacpotenciál növekedés következtében a gazdasági fejlődés útjára léphetnek. Abban az esetben, ha az integráció következtében a határrégiók vonzóképessége jelentősen nő, akkor más termelési központok dominanciája csökkenhet, így új központok alakulhatnak ki a határ mentén. Mindez pedig azért következhet be, hogy az új centrumok kihasználhassák a határokon átnyúló kínálati és keresleti tovagyürüző hatásokat. A korábbi központok ezzel párhuzamosan veszíthetnek

\footnotetext{
${ }^{5}$ Mindez a hagyományos lokalizációs elméleteknél is megjelenik. Ebből vezet le a NEG modell pótlólagos megközelítéseket: például a vállalatok közötti vertikális összekapcsolódást (Niebuhr - Stiller 2002b).
} 
gazdasági tevékenységeikből, s ennek okai között a külföldi piacok eléréséhez kapcsolódó magasabb költségeket találjuk.

A NEG modellek azonban nem csak az integráció pozitív hatását említik, hanem más tényezőkre is rámutatnak. Akkor ugyanis, ha a szállítási költségek szélsőségesen alacsonyak, a vállalatok nem lesznek érzékenyek aziránt, hogy közel vannak-e a piacokhoz vagy a beszállítókhoz. Továbbá az, hogy az integráció valóban hatással van-e gazdaságföldrajzi elhelyezkedésre, nagyban azon agglomerációs erők erősségétől függ, amelyek az integráció előtti ipari lokalizáció mintájának konzerválását erősítik (Hanson 1998a).

$\mathrm{Az}$ említett modellek nagy hiányossága, hogy statikusak és adottként értelmezik a gazdasági integráltság fokát. Ezáltal a feltételezések szerint az integráció kizárólag a gazdasági tevékenységek térbeli eloszlására lesz hatással, s nem érinti a gazdasági teljesítmény színvonalát. Ebből pedig az következik, hogy a határterület csak akkor növelheti gazdasági integráltságát, ha egy másik veszít abból. Mindebből pedig le kell vonnunk azt a következtetést, hogy a nemzetközi kereskedelmi költségek, a munkaerö és a vállalatok mobilitásának foka eredményezheti az EU-n belüli területi struktúra megváltozását.

A továbbiakban szeretnék rámutatni arra, hogy léteznek dinamikus szemléletű NEG modellek is, amelyek célja nem csak pillanatképszerü tájékoztatás nyújtása az integráció allokációs hatásának alakulásáról. Ezek tanulmányozása kiemelten fontos, hiszen az integráció hosszabb távon változtatja meg a gazdaság térszerkezetét.

Az első növekedést és gazdaságföldrajzot összekapcsoló megközelítések Martin (1999), illetve Martin és Ottaviano (1999) nevéhez füződnek. Ök maguk Romer-típusú (Romer 1990) endogén növekedést vezetnek be a gazdaságföldrajzi modellbe, párhuzamosan Krugman és Venables (1995), illetve Venables (1996) munkáival. Baldwin és Forslid (2000) a Romer-féle endogén növekedést a Krugman-féle centrum-periféria modellel kapcsolják össze. Azt azonban látnunk kell, hogy a dinamikus NEG modellekben az integráció területi kimenetele még mindig meghatározhatatlan. A statikusokhoz hasonlóan az eddig kifejlesztett dinamikus modellek sem adnak közvetlen következtetéseket a határrégiók fejlödésére. Ugyanez igaz a hagyományos és a legújabb növekedési modellekre, mivel a területi dimenziónak nem adnak nagy jelentőséget. Van azonban néhány olyan kutatás, amely igyekszik ezt a hiányosságot pótolni. Krugman és Venables (1995) például az integráció tükrében a gazdasági tevékenységek területi struktúrára gyakorolt hatását vizsgálták Európában, Brülhart és szerzőtársai (2004) modellje pedig egyedi következtetések levonására ad lehetőséget a határrégiók esetében. Az elméleti kutatások azonban nem adnak egyértelmű választ arra, vajon az európai kontinens központjában lévő régiók a perifériák kárára profitálnak-e az európai integrációból vagy sem. Arra viszont egyértelműen rámutatnak, hogy az integrációs folyamatban a centrifugális erők dominálnak (Brülhart et al 2004). Van Houtum (1998) doktori értekezésében továbbá arra mutat rá, hogy a globalizáció korszakában a határok centrifugális hatása eddig soha nem látott szinten ölt testet.

Mindezzel pedig a Krugman-féle új gazdaságföldrajz elmélet (1991) legföbb hipotézise kerül megerősítésre, amely szerint a gazdasági korlátok felszámolása és a szállítási költségek mérséklődése következtében a vállalatok áttelepülnek oda, ahol a növekvő skálahozadékú gazdasági tevékenységek erős koncentrációt mutatnak. A centrális fekvésủ területeken elhelyezkedő nagyobb piac vonzza a kisebb piacok vállalatait és dolgozóit, s ezáltal tovább 
növekszik a koncentráltság foka. ${ }^{6}$ A gazdasági interakció agglomerációs erői felszínre törnek tehát azokban a régiókban, ahol hatékony a piac mérete (Amiti 1998). A klasszikus modell rámutat még arra is, hogy a szállítási költségek valójában fontos szabályozó szerepet töltenek be a gazdasági tevékenységek területi elhelyezkedésében. Utóbbiak azonban az integráció magasabb fokán szórt elhelyezkedést mutatnak, ezáltal létrejöhet a teljes régióhoz való jobb hozzáférés. A központi határterületek földrajzi előnyt élveznek egy gazdasági unióban - úgy, hogy eröteljesen vonzzák a vállalatokat és a fogyasztókat. Ezen nézőpont szerint a központban, vagy a központ közelében elhelyezkedö határ menti területek nagyobb vonzóképességgel rendelkeznek. Ilyen területek Európában például a francia-belga, a német-osztrák és a német-holland határ menti régiók.

Természetesen a távolsági tényező és a regionális fejlődés kapcsolata az új gazdaságföldrajzi modelleknek is tárgya, s ezekben az domborodik ki, hogy a gazdasági koncentráció a piaci expanzió következtében tovább erösödik (Monfort - Nicolini 2000; Monfort - Ypersele 2003). A koncentrációt és az expanziót semmi sem torzíthatja, hiszen Krugman (1991) szerint a különböző nemzetgazdaságok a nemzetközi áru- és szolgáltatáskereskedelemben, a nemzetközi pénzmozgásokon keresztül ma sokkal jobban összekapcsolódnak, mint bármikor a múltban. Erről nyerhetünk tanúbizonyságot Henderson és Thisse (2004) révén, amikor azzal szembesítenek bennünket, hogy az Európai Unió 38 legnagyobb városa 2000ben az EU területének 0,6\%-án a lakosság 25\%-át tömörítette - úgy, hogy eközben a uniós GDP közel 30\%-a itt keletkezett.

Végezetül egy speciális aspektus a migráció. Ezen áramlások említése kapcsán rá kell mutatnunk a következőkre. Ha az integráció eredményeképpen a bérek növekednek a határ menti területeken és kedvezőbb a hozzáférés a magasabb vásárlóerejü területekhez, akkor nemcsak külső (országok közötti), hanem belső (országon belüli) migrációs áramlások is felszínre törhetnek (Fujita el al 1999)². Különösen igaz ez akkor, ha a centrifugális erők markánsabbak, mint a centripetálisak, mert ekkor az eredmény a vállalatok és a munkaerő területi terjedése lesz. Más tanulmányok rámutatnak arra is, hogy az integráció tovább súlyosbítja azon határterületek munkaerőpiacát, ahol regionális jelleg (országosnál súlyosabb helyzet) volt a határok felszámolása előtt (Niebuhr - Stiller 2004). Ugyanebben az irányban elmozdulva Buettner és Rinke (2004) empirikus kutatásokkal alátámasztja, hogy az integráció nyomán bekövetkező utazásiköltség-csökkenés a fejlettebb országok határ menti területein növeli az álláslehetőségek számát, ami később az átlagjövedelem csökkenéséhez és a munkanélküliség növekedéséhez vezet.

$\mathrm{Az}$ új gazdaságföldrajz elmélete ezen túl az azonos termelési struktúrával rendelkező országok úgynevezett intra-indusztriális kereskedelmi típusának leírására is alkalmas. E típus kapcsán azt jegyzi meg, hogy hasznosabb lehet a fejlettebb területek számára, ugyanis innovációra ösztönöz és kiaknázza a méretgazdaságossági előnyöket (Ruffin 1999). Az inter-indusztriális kereskedelem esetében pedig a kevésbé fejlett határ menti területek számára munkaintenzív specializációban való megrekedést vetít előre, ami a területi

\footnotetext{
${ }^{6}$ A modell egyébként egy kisebb, termelési tényezőkben gyengén ellátott, kis piaccal rendelkező, valamint egy nagyobb, termelési tényezőkkel bövebben, nagyobb piacmérettel ellátott régió világtermelésben való részarányát írja le. Az alapvető kérdésfelvetés az, hogyan befolyásolja a szállitási költségek alakulása a gazdasági integrációt a két régió között (Brakman et al 2001).

${ }^{7}$ A valóságban azonban a munkaerő mobilitásának teljes interregionális és internacionális feltételezése nem nyer megerősitést. Az újabb elemzések modelljeiben a munkaerő teljes mobilitásának feltételezése egyre szerényebb mértékben jelenik meg, és a nem tökéletes mobilitás esete nyer egyre nagyobb teret (Fujita et al 1999; Puga 1999).
} 
egyenlötlenségek növekedését vonhatja maga után (Panteladis 2002). Mindez természetesen megcáfolja a neoklasszikus kereskedelemelméletek premisszáit, amelyek szerint a regionális kereskedelem a specializáció és az árucsere révén a tőke- és a munkajövedelmek kiegyenlítődéséhez vezet (Samuelson 1964).

A különböző NEG modellek megállapításai szerint a határokleomlása után jelentősterületi dinamizmusok indulnak el. Az elméleti megközelítés azonban nem tudja egyértelmüen felvázolni a bekövetkezett változások irányát, előjelét a határ menti területek esetében. Empirikus kutatásokkal is alátámasztott tényként kíván megerősödni azonban az az állítás, hogy az olyan gazdasági integrációkban, mint az Európai Unió, a magterületek, vagy az azokhoz közel fekvő téregységek erőteljesen profitálhatnak a piacpotenciál növekedéséből. Ennek okaként pedig a magas termelési tényező és gazdasági tevékenység koncentráció említhető meg. A gyér tényezőellátottságú és gazdasági aktivitású határ menti területek pedig a kiterjedő globális tér és a kereskedelmi liberalizáció pozitív dinamizmusainak szerény mértékü haszonélvezői vagy vesztesei lehetnek.

\section{Következtetések}

Tanulmányomban arra tettem kísérletet, hogy a tovább folytatódó integráció tükrében felvázoljam azon téregységek fejlődési pályáját, amelyek életében jelentős befolyásoló szerepet tölt be az államhatár. Mindehhez három közgazdasági elmélet eddigi eredményeit hívtam segítségül. A telephely, a kereskedelem és az új gazdaságföldrajz elméleti álláspontjait tanulmányozva rá kellett mutatnom, hogy egyelöre a csökkenő kereskedelmi költségekhez kapcsolódó regionális átrendeződés domborodik ki az integráció területi hatásával kapcsolatosan. Bizonyos, hogy az integráció megváltoztathatja az erőforrások allokációját országokon belül éppen úgy, mint országok között. Sajnálatos tény viszont, hogy a nemzetközi tényezőáramlás hatása a gazdasági tevékenységek területi eloszlásában nem képez érdemi vizsgálati fókuszt. Mindössze néhány olyan tudományos igényességü munka áll rendelkezésre, amelyek alapján értékes következetéseket vonhatunk le. Ezeket a megállapításokat azonban kellő körültekintéssel kell kezelnünk, széleskörü általánosításra nincs lehetőség.

A hagyományos telephely és az új gazdaságföldrajzi modellek szerint a külső kereskedelem megváltoztathatja a belső gazdaságföldrajzi eloszlást, s ennek eredményeképpen új ipari központok jöhetnek létre. Ennek oka, hogy a gazdasági tevékenységek külső orientációja markánsabbá válik, mint a belső, mivel az integráció mind a vásárlók, mind a beszállítók esetében megváltoztatja a referenciapiacokat. Az ehhez kapcsolódó erőforrás-reallokáció pedig számos hasznot hozhat a határrégiók számára. A megnyíló határok hozzáférést biztosítanak a nagyobb piacokhoz, így a határterület vonzási potenciálja növekszik. A távolság és a piacméret tehát jelentősen meghatározza a határ mint kereskedelmet gátló akadály felszámolásából eredő centripetális és centrifugális erők egyensúlyát (Kallioras 2006, 2007; Topaloglou 2008; Topaloglou - Petrakos 2008). Az integrációs partnerekhez való területi közelség következtében a központi fekvésü határrégióknak költségelönyük lehet a szomszédos országokkal való kereskedelemben.

A piaci hozzáféréssel kapcsolatosan az új gazdaságföldrajz és a hagyományos telephely elméletek is számos állítással élnek, amelyek szerint a határok eltünése a fogyasztókat, a termelési tényezöket és a vállalatokat a központi határrégiókba vonzhatja, a földrajzilag hátrányos helyzetben lévő periférikus fekvésű régiók pedig nem szerezhetnek előnyt 
olyan mértékben a nemzetközi kereskedelemből, mint a centrális fekvésü területek, mert egyszerủen magasabb szállítási költségekkel kell szembenézniük (Limao - Venables 2001). Mindezt arra a tényre alapozza a két elméleti megközelítés, hogy az integráció növeli a már egyébként is gazdaságilag erősen integrált határrégiók piacpotenciálját. Egy gazdasági unión belül ezért a határokon átívelő backward és forward jellegủ tovagyürüző hatások olyan, önmagát erősítő agglomerációs hatást indíthatnak el, amelynek fő haszonélvezői a centrális elhelyezkedésü, határok mentén fekvő régiók lehetnek. Petrakos $(2000,2001)$ is megerősíti mindezt, amikor rámutat, hogy az olyan gazdaságok (régiók), ahol a növekvő skálahozadékú tevékenységek a dominánsak, jobb teljesítményt fognak mutatni, mint a kevésbé fejlettek. A fejletlenek továbbá lemaradással vagy a további periferizálódással néznek szembe. Ráadásul, ha még számos kereskedelmi korlátozás is érvényben van, a „sikeres” régiók többnyire a fövárosban (vagy annak közelében) fognak elhelyezkedni, a határok mentén megjelenő kereskedelmi akadályok ugyanis megnehezítik a gazdasági tevékenységek reallokációját a periférikus területek felé (Hoover 1963). Hansen (1983) a növekedési póluselméletek logikáját alkalmazva arra a következtetésre jutott, hogy a határ gátolja a központból a környezö területekre, vonzáskörzetre induló diffúziós hatásokat, akadályozza az innovációk terjedését. A határok megnyitásával ezen akadályok megszűnnek, a diffúziós folyamatok újraindulásával a centrumtérség erősíti pozícióját és később fejlődésnek indul.

A periférikus régiók számára pedig félő, hogy a távoli és a nagyobb partnerekkel való integrációs folyamatban egyensúlyhiányos fejlődési ív rajzolódik ki, amelyben az interindusztriális kereskedelmi kapcsolatok erősödnek, s ezek kedvezőtlen hatással vannak az ipari bázisra és konzerválják a fejletlenséget (Petrakos - Christodoulakis 1997).

Természetesen van néhány olyan tanulmány, amely a teljesen liberalizált kereskedelem mellett a kis piacméretü periférikus régiók sikerét említi. Ám rámutatnak arra is, hogy csak azok lehetnek képesek az integrációból származó előnyök kihasználására a piaciméretpotenciáljuk növelésével, amelyek egyébként is fejlettebbek (Alesina et al 2000). ${ }^{8}$ Túlsúlyban vannak azonban azok az elméleti alapokon nyugvó megállapítások, melyek azt említik, hogy az integrációs terület központjában elhelyezkedő határrégiók előnyt élvezhetnek az erőforrások vonzásában. A határrégiók területi közelsége a külföldi piacokhoz javítja a lokalizációs feltételeket. Az integráció pozitív hatással van a külső kereslethez való hozzáférésre, a piacpotenciálra és a határokon átnyúló backward és forward tovagyürűző hatások fejlődésére. Ezen megfontolásokra alapozva Hansonnal (1996) együtt arra a következtetésre juthatunk, hogy „a regionális kereskedelmi egyezmények ÉszakAmerikában és Európában nagy valószínűséggel a határzónák kiterjedését okozzák."

Ám ha kellően következetesek vagyunk, láthatjuk, hogy az említett elméletek nem adnak egyértelmü és tiszta következtetéseket a határ menti területek gazdasági jövőképéről. Még az is bizonytalan, hogy az integráció megváltoztatja-e egyáltalán a gazdaságföldrajzi elhelyezkedést. İgy még annak is rendkívül nehéz a megjóslása, mely régiók profitálhatnak az erőforrások reallokációjából egy gazdasági unión belül. A területi eloszlás változásában a leglényegesebb ugyanis a tényezők mobilitásának foka. Végső soron empirikus kutatások mutathatják meg, hogyan befolyásolja az erőforrások területi allokációját és a határ menti területek gazdasági fejlődését az integráció. Ráadásul a határrégiók gazdasági növekedését elősegítő folyamatokat hátrányosan érintik azok az erők, amelyek a gazdasági tevékenységek

8 Különösen igaz ez akkor, ha a szomszédos piac mérete jóval nagyobb, mint a belső (McCallum 1995; Damijan Kostevc 2002, Resmini 2002). 
integráció előtti földrajzi eloszlását konzerválták. Lényeges tehát, hogy bizonyos határ menti területek jövőképét és fejlődési mozgásterét kellő alaposságú empirikus kutatás segitségével vázoljuk fel, mert a közgazdasági elmélet csak nagyon homályos következtetéseket ad az integráció területi hatásairól. Az eltérő körülményektől függően a határrégiók profitálhatnak, veszíthetnek, vagy látókörön kívül kerülhetnek az integrációs dinamikák felszínre törése után.

\section{Hivatkozások}

Alesina, A. - Spolaore, E. - Wacziarg, R. (2000): Economic Integration and Political Disintegration. American Economic Review Vol. 90, 5:615-623.

Amiti, M. (1998): New Trade Theories and Industrial Location in the EU: A Survey of Evidence. The Oxford Review of Economic Policy Vol. 14, 2:45-53.

Anderson, J. - O’Dowd, L. (1999): Border, Border Regions and Territoriality: Contradictory Meanings, Changing Significance. Regional Studies Vol. 33, 7:593-604.

Baldwin, R. E. - Forslid, R. (2000): The Core-Periphery Model and Endogeneous Growth: Stabilising and Destablising Integration. Economia, Vol. 67:307-324.

Baranyi Béla (2007): A határmentiség dimenziói Magyarországon. Dialóg Campus Kiadó, Budapest-Pécs. Benko, G. (1999): Regionális tudomány. Dialóg-Campus Kiadó, Budapest-Pécs.

Bhabha, H. K. (1994): The location of culture. Routledge, London.

Boggs, W. (1940): International Boundaries: A Study of Boundary Funcions and Problems.: Columbia University Press, New York.

Brakman, S. - Garretsen, H. - Marrewijk, C. (2001): An introduction to geographical economics. Cambridge University Press, Cambridge.

Bröcker, J. (1984): How do International Trade Barriers affect Interregional Trade? In: Anderson, A. E. - Isard, W. - Puu, T. (ed.): Regional and Industrial Development Theories. North-Holland, Amsterdam:219-239.

Bröcker, J. (1990): Raumliche Wirkungen der europanishen Integration - ein Survey. Jahrbuch für Regionalwissenschaft 11:43-63.

Bruinsma, F. (1994): De Invloed van Transportinfrastructuur op Ruimtelijke Patronen van Economische Activiteiten. Nederlandse Geografische Studies, Utrecht/Amsterdam.

Brülhart, M. - Matthieu, C. - Pamina, K. (2004): Enlargement and the EU Periphery: The Impact of Changing Market Potential. Discussion Paper 270, Hamburg Institute of International Economics.

Brülhart, M. (1998): Economic Geography, Industry Location and Trade: The Evidence. World Economy Vol. 21, 6:775-801.

Buettner, T. - Rincke, J. (2004): Labour Market Effects of Economic Integration: The Impact of Re-unification in German Border Regions. CESifo Working Paper, 1179.

Christaller, W. (1933): Central Places in Southern Germany. Englewood Cliffs.

Church, A. - Reid, P. (1995): Transfrontier Co-operation, Spatial Development Strategies and the Emergence of a New Scale of Regulation: the Anglo-French Border. Regional Studies Vol 29, 3:294-316.

Clark, T. (1994): National Boundaries, Border Zones and Marketing Strategy: A Conceptual Framework and Theoretical Model of Secondary Boundary Effects. Journal of Marketing, 58:67-80.

Czimre Klára (2006): Cross-Border Co-operation - Theory and Practice. Kossuth Egyetemi Kiadó, Debrecen.

Damijan, J. - Kostevc, C. (2002): The Impact of European Integration on Adjustment Pattern of Regional Wages in Transition Countries: Testing Competitive Economic Geography Models. Discussion Paper 118, Center for Transition Economics.

Dimitrov, M. - Petrakos, G. - Totev, S. - Tsiapa, M. (2002): Cross-Border Cooperation in Southeastern Europe: The Enterprises' Point of View. Eastern European Economies, Vol. 41, 5:5-25.

Elizondo, P. L. - Krugman, P. (1996): Trade Policy and Third World Metropolis. In: Journal of Development Economics, Vol. 49:137-150.

Engel, C. - Rogers, J. H. (1996): How wide is the border? American Economic Review, Vol. 86, No. 5, December:1112-1125. 
Erdősi Ferenc (1988): A határmenti térségek kutatásáról. OKKFT Ts-2/2 „A terület- és településfejlesztés társadalmi-gazdasági folyamatai Magyarországon" címü program. A sajátos helyzetü térségek területés településfejlesztési problémái. Az 1986. november 4-5-én Szombathelyen tartott tudományos tanácskozás anyaga. MTA RKK, Pécs:18-30.

Fischer, P. A. - Straubhaar, T. (1996): Migration and Economic Integration in the Nordic Common Labour Market. Nordic Concuil of Ministers, Copenhagen.

Fujita, M. - Krugman, P. - Venables, A. (1999): The Spatial Economy: Cities, Regions, and International Trade. MIT Press, Cambridge MA.

Fujita, M. - Mori, T. (1996): The role of ports in the making of major cities: self-agglomeration and hubeffect. Journal of Development Economics, Vol. 49, No. 1:93-120.

Giersch, H. (1949/1950): Economic Union beetween Nations and the Location of Industries. Review of Economic Studies, Vol. 17:87-97.

Guo, R. (1996): Border-Regional Economics. Heidelberg.

Haggett, P. (2006): Geográfia - Globális szintézis. Typotex Kiadó, Budapest.

Hansen, N. (1983): International Co-operation in border regions: an overview and research agenda. International Regional Sciences Review, Vol. 8, 3:255-270.

Hansen, N. (1986): The nature and significance of transborder cooperation in the Mexico-US borderlands: Some empirical evidence. Journal of Borderland Studies, Vol. 1, 2:57-65.

Hanson, G. (1996): Integration and the Location of Activities: Economic Integration, Intra-industry Trade, and Frontier Regions. European Economic Review, Vol. 40:941-949.

Hanson, G. (1998a): Regional Adjustment to Trade Liberalisation. Regional Science and Urban Economics, Vol. 28:419-444.

Hanson, G. H. (1998b): Market Potential, Increasing Returns, and Geographic Concentration. NBER Working Paper, No. 6429.

Hardi Tamás (2008): A határtérség térszerkezeti jellemzői. Tér és Társadalom, XXII. évf., 3. szám:3-25.

Harris, J. R. - Todaro, M. P. (1970): Migration, Unemployment and Development: A Two-Sector Analysis. American Economic Review, Vol. 60:126-142.

Heigl, F. (1978): Ansatze einer Theorie der Grenze. Österreichischen Gesellschaft für Raumforschung und Raumplannung (Bd. 26.), Wien.

Henderson, V. - Thisse, J. F. (eds.) (2004): Handbook of Regional and Urban Economics. Cities and Geography, Vol. 4., Elsevier, Amsterdam.

Hoover, E. (1963): The Location of Economic Activity. McGraw-Hill, Berkshire.

Janssen, M. (2000): Borders and Labour-Market Integration: Where is the Differences between Interregional and Cross-border Mobility? In: Van der Velde, M. - Van Houtum, H. (eds.): Borders, Regions, and People. European Research in Regional Science, Pion, London, Vol. 10:47-68.

Kallioras, D. - Topaloglou, L. - Venieris, S. (2009): Tracing the Determinants of Economic Cross-border interaction in the European Union. SPATIUM International Review, 21:1-10.

Kallioras, D. (2006): Patterns of Regional Development of the EU New Member States: The Heterogeneous Impact of Geography. Aichoros 5, 2:46-67.

Kallioras, D. (2007): Regional and Sectoral Impact of the EU Enlargement on the EU New Member States. $\mathrm{PhD}$ thesis. Volos: Department of Planning and Regional Development, University of Thessaly.

Kamann, D. J. F. (1993): Bottlenecks, Barriers and Networks of Actors. In Ratti, R. - Reichman, S. (ed.): Theory and Practice of Transporter Cooperation. Verlag Helbing and Lictenhahn, Basel and Frankfurt am Main: 65-102.

Kovács András (2010): Kereskedelem határok nélkül - A határ menti kiskereskedelem sajátosságai a szlovákmagyar határtérség nyugati felében. PhD-tézisek. Széchenyi István Egyetem, RGDI, Győr.

Krakover, Sh. (1997): Boundary Opennes Model Applied to Israel, Egypt and Gaza Strip Tri-border Area. Paper presented at the European Regional Science Association Summer Institure, Are.

Krugman, P. - Venables, A. J. (1995): Globalisation and the inequality of nations. The Quarterly Journal of Economics, Vol. 110:857-880.

Krugman, P. R. (1991): Geography and Trade. MIT Press, Cambridge, Massachusetts. (Magyarul megjelent: Földrajz és Kereskedelem. Nemzeti Tankönyvkiadó, Budapest, 2003).

Le Gales, P. - Lequesne, C. (eds.) (1998): Regions in Europe. Routledge, London.

Limao, N. - Venables, A. (2001): Infrastructure, Geographycal Disadvantage and Transport Costs. World Bank Economic Review Vol. 15, 3:451-479.

Lösch, A. (1944/1945): The Economics of Location. Yale University Press, New Haven. 
Ludema, R. D. - Wooton, I. (1999): Regional Integration, Trade and Migration: Are Demand Linkages relevant in Europe? In: Faini, R. - De Melo, J. - Zimmermann, F. (eds.): Migration - The controversies and the evidence.

Mackay, J. R. (1958): The Interactance Hypothesis and Boundaries in Canada. Canadian Geographer, Vol. 11:1-8.

Martin, R. L. (1999): The new 'geographical turn' in economics: Some critical reflections. Cambridge Journal of Economics, Vol. 23:65-91.

Martin, P. - Ottaviano, G. M. (1999): Growing Locations: Industry location in a model of endogenous growth. European Economic Review, Vol. 43:281-302.

Martinez, O. (ed.) (1986): Across boundaries: Transborder interaction in comparative perspective. Texas Western Press, El Paso.

McCallum, J. (1995): National Border Matter: Canada-US Regional Trade Patterns. American Economic Review, Vol. 85:615-623.

Mendöl Tibor (1963): Általános településföldrajz. Akadémiai Kiadó, Budapest.

Monfort, P. - Nicolini, R. (2000): Regional Convergence and International Integration. Journal of Urban Economies, Vol. 48:286-306.

Monfort, P. - Ypersele, T. (2003): Integration, Regional Agglomeration and International Trade. Research Paper 3752, Center for Economic Policy.

Niebuhr, A. - Stiller, S. (2002a): Integration and Labour Markets in European Border Regions. HWWA Discussion Paper, 179.

Niebuhr, A. - Stiller, S. (2002b): Integration Effects in Border Regions - A survey of Economic Theory and Empirical Studies. HWWA Discussion Paper, 179.

Niebuhr, A. - Stiller, S. (2004): Integration and Labour Market sin European Border Regions. HWWA Discussion Paper, 284.

Nijkamp, P. - Rietveld, P. - Salomon, I. (1990): Barriers in Spatial Interactions and Communication. A Conceptual Exploratio. Annals of Regional Science, Vol. 24, 4:237-252.

Nijkamp, P. (1993): Border region and infrastructure networks in European integration processes. Environment and Planning C: Government and Policy, Vol. 11, 4:431-446.

Nuesser, H. G. (1985): Die Bedeutung von Hemmnisfaktoren für die Entwicklung des Verkehrsaufkommes. DFVLR-Nachrichten 45:32-34.

Ohlin, B. (1967): Interregional and International Trade. Harvad University Press, Cambridge, MA.

Ohmae, K. (1995): The End of the Nation State: The Rise of Regional Economies. Free Press, London.

Paasi, A. (1996): Territories. Boundaries and Consciousness: The Changing Geographies of the FinnishRussian Border. John Wiley, Chichester.

Panteladis, G. (2002): Geography and Integration: The Case of Greece as a Future Image for the Transition Countries of the Balkans. In: Kotios, A. - Petrakos, G. (ed.): Restructuring and Development in Southeastern Europe. Volos: South and European Development Center and University of Thessaly Press: 377-413.

Petrakos, G. - Christodoulakis, N. (1997): Economic Development in the Balkan Countries and the Role of Greece: From Bilateral Relations to the Challenge of Integration. Discussion Paper 1620, Centre for Economic Policy Research.

Petrakos, G. - Topaloglou, L. (2008): Economic Geography and European Integration: The Effects of on the EU External Border Regions. International Journal of Public Policy, Vol. 3, 3/4:146-162.

Petrakos, G. (2000): The Spatial Impact of East-West Interaction in Europe. In: Petrakos, G. - Maier, G. - Gorzelak, G. (eds.): Integration and Transition in Europe: The Economic Geography of Interaction. Routledge, London:38-68.

Petrakos, G. (2001): Patterns of Regional Inequality in Transition Economies. European Planning Studies, 9, 3:359-383.

Poincaré, J. H. (1909): L’Avenir des mathimatigis. In: Attidel IV. Congress Internacionale dei Matematici. Real Academie dei Lincei, Rome:169.

Puga, D. (1999): The Rise and Fall of Regional Inequalities. European Economic Review, Vol. 43:303-334.

Ratti, R. (1993): Spatial and Economic Effects of Frontiers: Overview of Traditional and New Approaches and Theories of Border Area Development. In: Ratti, R. - Reichman, S. (ed.): Theory and Practice of Transporter Cooperation. Verlag Helbing and Lictenhahn, Basel and Frankfurt am Main:23-53.

Rauch, J. E. (1991): Comparative Advantage, Geographic Advantage and the Volume of Trade. The Economic Journal, Vol. 101:1230-1244. 
Rechnitzer János (1999): Határ menti együttmüködések Európában és Magyarországon. In: Nárai Márta Rechnitzer János (szerk.): Elválaszt és összeköt - a határ. MTA RKK, Győr-Pécs:9-72.

Resmini, L. (2002): European Integration and Adjustment in Border Regions in Accession Countries. Paper presented at the 42nd European Congress of the European Regional Science Association, August 2731, Dortmund, Germany.

Rietveld, P. - Janssen, L. (1990): Telephone Calls and Communication Barriers, The Case of the Netherlands. The Annals of Regional Science, 24:307-308.

Romer, P. M. (1990): Endogenous Technological Change. Journal of Political Economy, Vol. 98:71-102.

Ruffin, R. (1999): The Nature and Significance of Intra-Industry Trade. Economic and Financial Policy Review, 1999 (4):1-8.

Ruttkay Éva (1995): Határok, határmentiség, regionális politika. Comitatus Önkormányzati Szemle 12:2335.

Samuelson, P. (1964): Theoretical Notes on Trade Problems. Review of Economics and Statistics, Vol. 46, 2:145-154.

Schwartz, B. K. Jr. (1973): Mound Three, White Site Hn-10 (IAS-BSU): The Final Report on a Robbins Manifestation in East Central Indiana. Muncie State University Contributions to Anthropological History, 1.

Scott, J. W. (1998): Planning cooperation and transboundary regionalism: Implementing policies for European border regions in the German-Polish context. Environment \& Planning C: Government and Policy, Vol. 16:605-624.

Sjaastad, L. A. (1962): The Costs and Returns of Human Migration. Journal of Political Economy, Vol. 70:80-93.

Slowe, P. M. (1991): The geography of borderlands: The case of the Quebec-US borderlands. The Geographical Journal, Vol. 157, 2:191-198.

Suarez-Villa, L. (1992): Twentieth Century U.S. Regional and Sectoral Change in Perspective. Survey of Regional Literature, Vol. 20:32-39.

Tassinopoulos, A. (1999): Migration of Labour in the European Union. In: De Gijsel, P. - Janssen, M. Wenzel, J. - Woltering, M. (eds.): Understanding European Cross-Border Labour Markets: Issues in Economic Cross-Border Relations. Metropolis-Verlag, Marburg:207-215.

Thrift, N. (1996): New Urban Eras and Old Technological Fears: reconfiguring the goodwill of electronic things. Urban Studies, Vol. 33, 8:1463-1494.

Todaro, M. (1969): A Model of Labour Migration and Urban Development in Less Developed Countries. American Economic Review, Vol. 59:138-148.

Topaloglou, L. - Petrakos, G. (2008): Borders, Integration and Development: The New Geography of CrossBorder Relations. Kritiki, Athens.

Topaloglou, L. (2008): Borders and Integration: Space, Economy, Policies. PhD Thesis. Volos: Department of Planning and Regional Development.

Tovias, A. (1991): A Survey of the Theory of Economic Integration. In: Journal of European Integration, Vol. 15:5-23.

Trón Zsuzsanna (2009): Az Európai Unió regionális politikájának céljai és eredménye. Debreceni Egyetem, Egyetemi doktori értekezés, kézirat.

Van Houtum, H. (1998): The Development of Cross-Border Economic Relations. ThelaThesis Publishers, Amsterdam:12-13.

Van Houtum, H. (2000): An overview of European Geographical Research on Borders and Border Regions. Journal of Borderlands Studies, Special Issue on European Perspectives on Borderlands, Vol. 15, No. 1:57-85.

Venables, A. J. (1996): Equilibrium Locations of Vertically Linked Industries. In: International Economic Review, Vol. 37, No. 2:341-359.

Von Malchus, V. F. (1994): Nouvelles possibilities de cooperation transfrontaliere en Europe Centrale et de l'Est. 5e Conférence européenne des régions frontaliéres. Rovaniemi (Finlande), Strasbourg:69-85.

Williams, A. M. - Balaz, V. - Bodnarovna, B. (2001): Border regions and trans-border mobility: Slovakia in economic transition. Regional Studies, Vol. 35, 9:831-846.

Wilson, T. - Donnan, H. (1998): Border Identities: Nation and State at International Frontier. Cambridge University Press, Cambridge. 